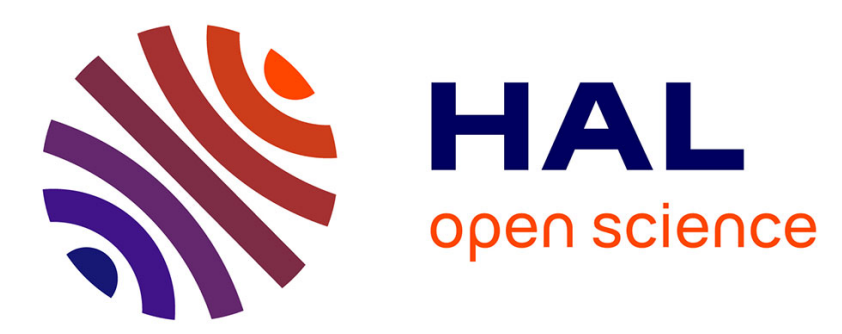

\title{
Blue light induces DNA damage in normal human skin keratinocytes
}

Cécile Chamayou-robert, Olivier Brack, Olivier Doucet, Carole Di Giorgio

\section{To cite this version:}

Cécile Chamayou-robert, Olivier Brack, Olivier Doucet, Carole Di Giorgio. Blue light induces DNA damage in normal human skin keratinocytes. Photodermatology, Photoimmunology \& Photomedicine, 2022, 38, pp.69-75. 10.1111/phpp.12718 . hal-03375888

\section{HAL Id: hal-03375888 https://hal-amu.archives-ouvertes.fr/hal-03375888}

Submitted on 11 Jan 2022

HAL is a multi-disciplinary open access archive for the deposit and dissemination of scientific research documents, whether they are published or not. The documents may come from teaching and research institutions in France or abroad, or from public or private research centers.
L'archive ouverte pluridisciplinaire HAL, est destinée au dépôt et à la diffusion de documents scientifiques de niveau recherche, publiés ou non, émanant des établissements d'enseignement et de recherche français ou étrangers, des laboratoires publics ou privés. 


\section{Blue Light induces DNA-damage and may contribute to chromosome aberrations in normal human skin keratinocytes}

Cécile Chamayou-Robert ${ }^{1}$, Carole DiGiorgio ${ }^{2}$, Olivier Brack ${ }^{3}$, Olivier Doucet ${ }^{1}$

${ }^{1}$ COTY LANCASTER R\&D, Technology \& Innovation Laboratories

cecile robert@cotyinc.com

olivier doucet@cotyinc.com

${ }^{2}$ Laboratoire de Mutagénèse Environnementale, Aix-Marseille Université, CNRS, IRD, Avignon Université, IMBE UMR 7263

carole.di-giorgio@univ-amu.fr

${ }^{3}$ K.S.I.C., Statistique Industrielle $-\mathrm{Khi}^{2}$ - Consulting, 347 rue des sources

olivier.brack@wanadoo.fr

Cécile Chamayou-Robert and Carole DiGiorgio should be considered joint first author

\section{Correspondence}

Cécile Chamayou-Robert, Coty Lancaster R\&D Technology \& Innovation Laboratories,

cecile robert@cotyinc.com 


\begin{abstract}
Background: The generation of DNA damage by ultra-violet radiations (UV) is well established, and both the nature of the DNA lesions and their respective DNA-repair pathways, have largely been described. Besides UV rays, visible light constitutes a very important part of the sun spectrum where blue light is considered a significant contributor to premature aging. However, blue light-induced DNA damage has not been deeply explored yet.

Methods: In the present study, we assessed in human skin keratinocytes the DNA and Chromosome damaging activities of blue light rays $(415 \mathrm{~nm})$ as well as their associated DNA-repair mechanisms.

Results: Our results demonstrated that blue light induced dose-dependent DNA-damage in human keratinocytes. Both Oxidative and Cyclobutane-Pyrimidine-Dimers (CPD) DNA-lesions were generated. They were repaired through base excision repair (BER) and nucleotide excision repair (NER) pathways, respectively. Moreover, by using the Micronucleus assay we demonstrated, for the first time, that a blue wavelength exerted a clastogenic/aneugenic effect in human keratinocytes, leading to chromosome heritable aberration.

Conclusion: We concluded that, in normal human keratinocytes, blue light creates genotoxic lesions which might accelerate or at least contribute to premature skin aging.
\end{abstract}

\title{
Keywords
}

Blue light, DNA damage, DNA repair, keratinocytes

\section{Introduction}


Blue light (400-500nm) takes part of the visible electromagnetic spectrum. Natural sunlight blue wavelengths, which are always mixed with green, yellow and red wavelengths, have been shown to play an important role in the regulation of sleeping patterns and circadian rhythms. ${ }^{1}$ However, since the 1980 s the development of light-emitting diodes (LED) without red and near infrared wavelengths, and the concomitant exponential use of digital technologies, such as flat-screen TVs, computers, tablets and smart phones, have led to a drastic increase of human exposure to blue light ${ }^{2}$ and to several concerns about their possible involvement in the development of degenerative eye diseases. Moreover, the expansion of therapeutic protocols using blue light irradiation in several dental treatments and dermatologic therapies, has highlighted their potential sideeffects. ${ }^{3}$

The toxic and genotoxic effects of blue wavelengths have mainly been studied in the context of their therapeutic and ocular risks: they have been shown to induce cellular dysfunction and cell death in gingival fibroblasts ${ }^{4}$ and lens epithelial fibroblasts ${ }^{5}$, to generate sister-chromatid exchanges and endoreduplicated chromosomes in $\mathrm{CHO}$ cells ${ }^{6}$, and to cause deoxyribonucleic acid (DNA) strand-breaks in retinal pigment epithelial cells. ${ }^{7}$ Blue wavelengths near ultra-violet A (UVA) (400-450 nm), shown to be the most energetic visible wavelengths, have been supposed to produce the most important adverse effects in mammalian cells 8 , mainly through the extracellular and intracellular photosensitized production of Reactive Oxygen Species (ROS). ${ }^{9}$ However, direct interactions with DNA-bases have been also demonstrated. ${ }^{7}$ Concerning cutaneous exposure, it has been shown that blue wavelengths penetrate into the skin ${ }^{10}$ and induce both ROS production and cell death., ${ }^{911}, 12$ Recent studies have shown that blue light can also induce DNA damage in keratinocytes ${ }^{13,14}$ but the identification of the DNA lesions have been poorly studied.

In the present work, we attempted to study the DNA-damaging activity of blue light (415 nm), its DNA-repair mechanisms, and its resulting chromosome damage in human skin cells. Blue light induced DNA-damage and DNA-repair were evaluated by the comet assay in human normal keratinocytes, the predominant cell type in the epidermis. ${ }^{15,}{ }^{16}$ Chromosome mutations resulting from unrepaired DNA double-strand breaks and chromosome segregation abnormalities were measured by the micronucleus assay. ${ }^{17}$

\section{Materials and methods}

\subsection{Chemicals and cell cultures}

All reagents for cell cultures were purchased from Dutscher (Brumath, France), except bovine pituitary extract, recombinant epidermal growth factor (rEGF) and keratinocyte serum-free medium (K-SFM) which were from GIBCO-BRL (Life Technology, Cergy Pontoise, France). All chemicals for the comet and the micronucleus assays were purchased from Sigma-Aldrich (Saint Quentin Fallavier, France). Human Epidermal Keratinocytes Neonatal were purchased from ScienCell Research Laboratories. They were maintained in "Keratinocytes-SFM" medium supplemented with bovine pituitary extract $(30 \mu \mathrm{g} / \mathrm{ml})$ and recombinant epidermic growth factor (rEGF, 0.2 $\mathrm{ng} / \mathrm{ml}$ ). Cultures were performed in a $37^{\circ} \mathrm{C}$ humidified incubator with $5 \% \mathrm{CO}_{2}$ atmosphere.

\subsection{Irradiation procedure}

Blue light irradiation was carried out with a Biolambda blue light irradiator (Biolambda, Sao Paulo, Brasil) equipped with $415 \mathrm{~nm} \mathrm{LED}$, at an irradiance of $8 \mathrm{~mW} / \mathrm{cm}^{2}$. Before irradiation, well covers were removed and cells were irradiated with $4.8 \mathrm{~J} / \mathrm{cm}^{2}, 9.6 \mathrm{~J} / \mathrm{cm}^{2}$, and $14.4 \mathrm{~J} / \mathrm{cm}^{2}$ for the standard comet assay and the micronucleus assay, and $9.6 \mathrm{~J} / \mathrm{cm}^{2}$ for DNA-repair kinetics.

UVA/visible irradiation was carried out with a Suntest CPS+ solar simulator (Atlas Material Testing Technology BV, Moussy le Neuf, France) equipped with a xenon arc lamp (1100 W) and special glass filters (ID65) restricting transmission of light below $290 \mathrm{~nm}$ and near IR-blocking filter. The irradiation intensity was fixed at 76.5 $\mathrm{mW} / \mathrm{cm}^{2}$, and cells were irradiated with $15 \mathrm{~J} / \mathrm{cm}^{2}$. UVB irradiation was carried out with an UV irradiator Bio-Sun (Vilbert Lourmat, Marne la Vallée, France). The irradiator was equipped with a monochromatic UVB lamp, which delivered a calibrated computer-assisted beam of $312 \mathrm{~nm}$ wavelength at an irradiance of $0.91 \mathrm{~mW} / \mathrm{cm}^{2}$, and cells were irradiated with $0.08 \mathrm{~J} / \mathrm{cm}^{2}$. Blue-light, UVA and UVB doses have been selected for their low impact on 
cell survival, as assessed by neutral red uptake assay (more than $90 \%$ cell viability as compared to the nonirradiated cells) ${ }^{18}$.

\subsection{Comet assay}

The standard alkaline comet assay was performed as described by Singh et al. ${ }^{19}$, and a modified protocol has been used to improve the sensitivity of the assay by the use of specific enzymes: FPG, the formamidopyrimidine DNA glycosylase, which allows detecting 8-oxoguanine and other purine oxidation products formed when cell nuclei are exposed to oxidative stress and which specifically recognizes oxidized DNA-bases to convert them into strand-breaks ${ }^{20}$; T4 endonuclease $V$, the specific DNA-repair protein that recognizes cyclobutane pyrimidine dimers (CPD) and cleave them to form detectable strand-breaks, allows detecting the most abundant DNAlesions induced by UVB ${ }^{21}$.

Briefly, cells monolayers were irradiated before trypsinization. Cells pellets were suspended in agarose and deposited onto microscope slides, then immersed in lysis solution for $90 \mathrm{~min}$ at $4^{\circ} \mathrm{C}$. After the lysis procedure, slides were washed with BSA enzymatic buffer and treated with T4 endonuclease $V$, or with FPG for 30 minutes at $37^{\circ} \mathrm{C}$ in a humidified chamber. Electrophoresis was then carried out for 20 minutes at $25 \mathrm{~V}$ and $300 \mathrm{~mA}$. Finally, the slides were washed with $0.4 \mathrm{M}$ Tris buffer ( $\mathrm{pH} 7.5$ ), dehydrated in $100 \%$ methanol and dried for 12 hours at room temperature. Each slide was stained with $50 \mu \mathrm{l} \mathrm{of} 2 \mu \mathrm{g} / \mathrm{ml}$ ethidium bromide and examined at $250 \mathrm{X}$ Magnification using a BX53-RFL fluorescence microscope (Olympus Optical Co., Tokyo, Japan) equipped with a U-MWG2 dichroic mirror (band-pass filter, 510-550 nm; long-pass filter, $590 \mathrm{~nm}$ ) and a UPLFLN 20x objective. Image analysis was performed using the Komet software (version 6.0 Andor Technology, Belfast, Northern Ireland). A total of 50 randomly selected cells were analyzed per slide using Fenestra Komet 6.0 image analysis software (Andor Technology, Belfast, Northern Ireland). DNA damage was expressed as the Olive Tail Moment (OTM; arbitrary units); 100 OTM values were determined for each sample, 50 from each of two separate slides/sample.

The 100 calculated OTM values by sample were distributed into 40 classes between the minimal and the maximal values: each class interval corresponded to 1.4 OTM arbitrary units. A non-linear regression analysis was performed on the OTM distribution frequencies by using a $\chi^{2}$ function with TableCurve 2D software (version 5.0; Jandel Scientific Software, San Rafael, CA). The calculated degrees of freedom (n) for this function were quantitative measures of the DNA damage for a sample. ${ }^{22}$ The $n$ was termed $\chi^{2}$ OTM and was used as the sole parameter for assessing levels of DNA damage. The significance of the differences between $\chi^{2}$ OTM values of non-irradiated and irradiated cells was analysed using Student's t-test. The percentage of DNA-damage (\% DNAdamage) was determined as follows:

$$
\begin{aligned}
& \% \text { DNA-damage }=\left[\frac{\left(\chi^{2} \text { OTM }_{T X}-\chi^{2} \text { OTM }_{C 0}\right)}{\left(\chi^{2} \text { OTM }_{T 0}-\chi^{2} \text { OTM }_{C 0}\right)}\right] x \mathbf{1 0 0} \\
& \chi^{2} \text { OTM }_{T \times}: \chi^{2} \text { OTM of irradiated cells at each incubation time } \\
& \chi^{2} \text { OTM }_{\text {co: }} \chi^{2} \text { OTM of non-irradiated cells } \\
& \chi^{2} \text { OTM }
\end{aligned}
$$

\subsection{Micronucleus assay}

The micronucleus assay was performed according to the cytokinesis-blocked standard method. ${ }^{23,}{ }^{24}$ Keratinocytes were cultured for 24 hours in tissue culture chambers. Culture medium was replaced by sterile PBS and cells were submitted to irradiation. After irradiation, cells were grown in complete culture medium containing $3 \mu \mathrm{g} / \mathrm{ml}$ of cytochalasin B for 48-hour. Cells were fixed with methanol and stained with $10 \%$ Giemsa for 30 minutes. Micronuclei analysis was performed under a microscope at $\times 1000$ magnification. The rates of micronuclei were evaluated for the presence of independent nuclear core entities in a total amount of 5,000 binucleated cells. Micronuclei were identified as small nuclei well differentiated from cell nucleus, stained in the same manner and having a diameter less than one third of that of the cell nucleus. Micronuclei rates obtained for different exposure conditions were compared to the negative control by a Chi-squared test of independence in contingency tables.

\section{Results}




\subsection{Blue-light dose-dependent DNA-damage}

Figure 1 displays examples of intact and damaged nuclei observed with fluorescent microscope for the comet assay. Figure 2 displays Olive Tail Moment (OTM) distributions and the corresponding $\chi^{2}$ OTM in human keratinocytes irradiated with blue light at different irradiation times. Nuclei appeared as condensed spherical spots with low levels of single-strand breaks in non-irradiated cells (OTM median $=0.32-\chi^{2}$ OTM $=2.06 \pm 0.03$ ). In irradiated cells, nuclei appeared as the shape of a comet, with a small tail formed by the migration of DNA fragments from the nucleus towards the anode. Blue light-irradiation generated a dose-dependent increase of DNA-damage: a significant photo-induced DNA-damage was obtained from an irradiation dose of $9.6 \mathrm{~J} / \mathrm{cm}^{2}$ (OTM median $=2.21-\chi^{2}$ OTM $\left.=2.43 \pm 0.26, \mathrm{P}<0.001\right)$.

FIGURE 1. Examples of intact and damaged nuclei observed with fluorescent microscope for the comet assay

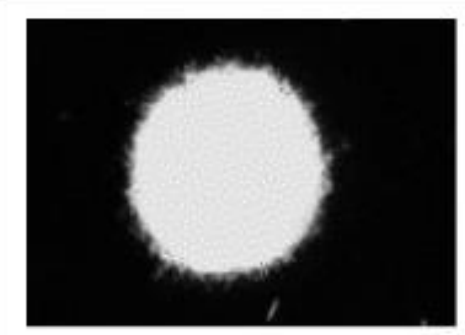

Non-irradiated cells

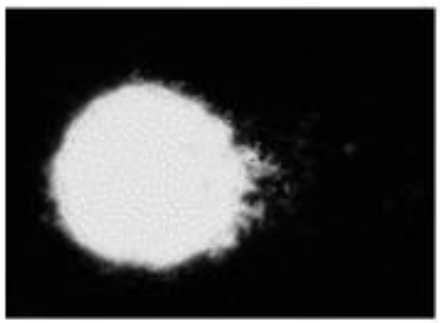

Blue light $14.4 \mathrm{~J} / \mathrm{cm}^{2}$

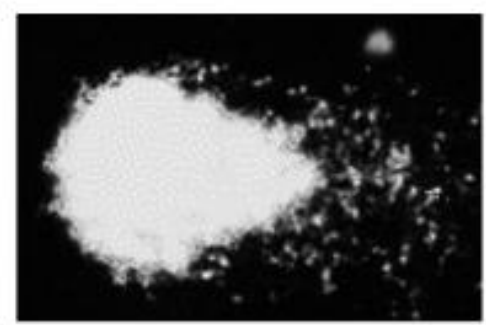

UVA $15 \mathrm{~J} / \mathrm{cm}^{2}+$ FPG

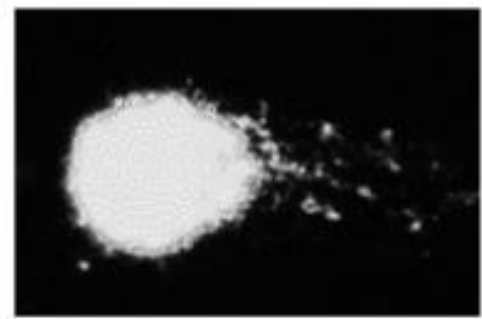

Blue light $14.4 \mathrm{~J} / \mathrm{cm}^{2}+F P G$

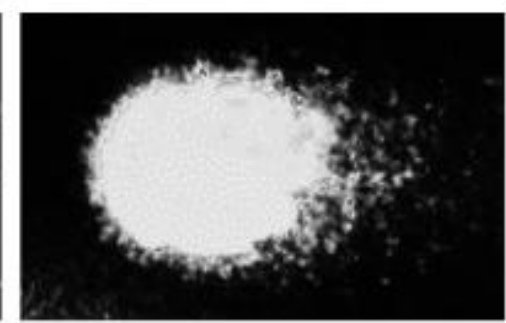

UVB $0,08 \mathrm{~J} / \mathrm{cm}^{2}+\mathrm{T} 4$ endo V

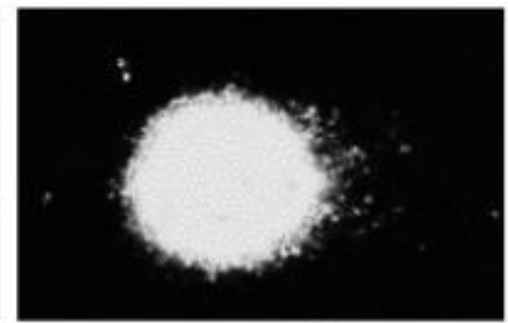

Blue light $14.4 \mathrm{~J} / \mathrm{cm}^{2}+\mathrm{T} 4$ endo $\mathrm{V}$

\subsection{Blue-light oxidative DNA-damage and CPD-lesions}

In blue-light irradiated cells, a significant dose-dependent increase of tail moment (OTM and $\chi^{2}$ OTM) was observed from the lowest exposure dose of $4.8 \mathrm{~J} / \mathrm{cm}^{2}$ (Figure 2), with FPG (median $=3.55-\chi^{2}$ OTM $=2.99 \pm 0.11$ ) or T4 endo V (median $=2.66-\chi^{2}$ OTM $=2.94 \pm 0.12$ ). Cleavage of oxidized bases and base-dimers by FPG and T4 endo $\mathrm{V}$ respectively resulted in a strong enhancement of the tail moment, indicating that blue light generated both oxidative DNA-damage and CPD-lesions.

\subsection{DNA-repair kinetic of oxidative DNA-damage and CPD-lesions}

An immediate time-dependent decrease of DNA-lesions could be observed in all the irradiated cells, indicating the rapid involvement of DNA-repair mechanisms after irradiation (Figure 3). Oxidative DNA-lesions, detected through the cleavage of oxidized-bases into apurinic sites by FPG, were totally repaired after a 60-minute incubation period for UVA/visible light irradiation, and after a 40-minute incubation period for blue light irradiation. The repair of CPD-lesions, identified through the cleavage of glycosyl and phosphodiester bonds by T4 Endo V, was slower. A consistent decrease of CPD-lesions could be observed during the first 6 hours after irradiation. Then DNA-repair was less efficient and, after 24 hours, the percentage of unrepaired CPD reached $13 \%$ in blue light exposed cells and $40 \%$ in UVB-exposed cells. 
FIGURE 2. OTM and $\chi^{2}$ OTM distributions in human keratinocytes exposed to UVA, UVB, and blue light (Comparisons between non-irradiated cells and irradiated cells were performed using Student's $t$ test. $* * *: P<.001)$
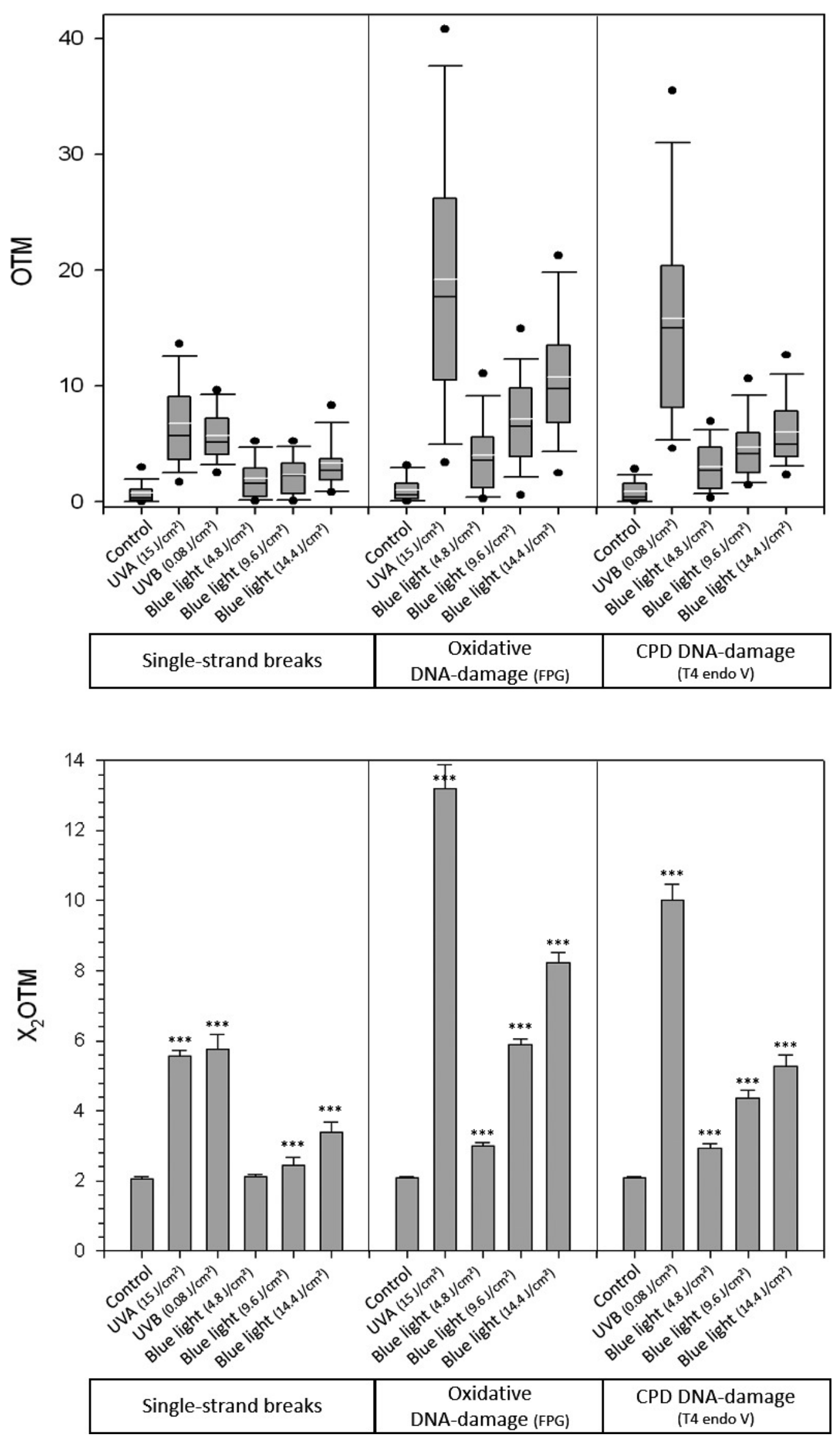
FIGURE 3. DNA repair kinetics on keratinocytes exposed to UVA/visible, UVB, and blue light (mean $\pm S D, n=4$ independent experiments)
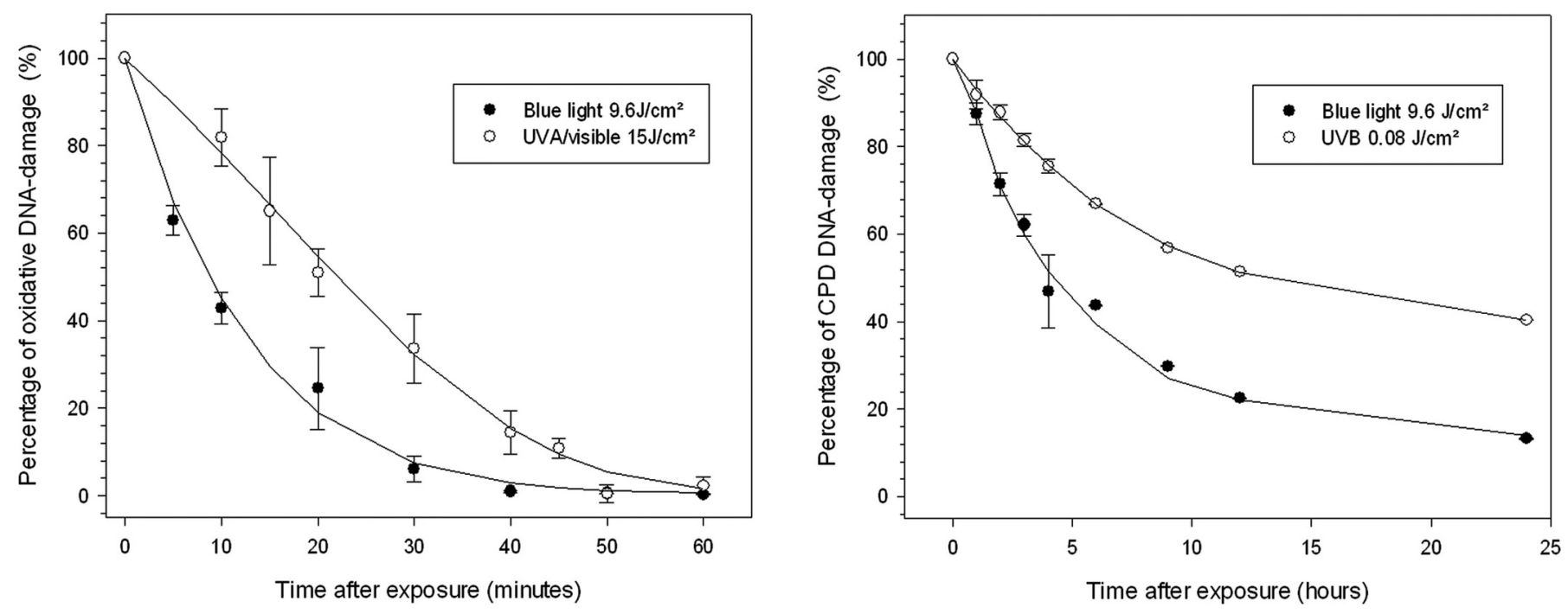

\subsection{Mutagenic impact of blue light irradiation}

Micronuclei appeared as small nuclear inclusions in the cytoplasm of interphase cells (Figure 4), with diameters varying between $1 \%$ and $9 \%$ of the cell diameter. In blue light irradiated cells, a dose-dependent increase of micronucleated cell levels could be observed (Table I). Induction of micronucleated cell was not significant for the irradiation doses of 4.8 and $9.6 \mathrm{~J} / \mathrm{cm}^{2}$ (mean $=9.80 \pm 0.84 \%$ - median $=9.90 \%$ and mean $=12.60 \pm 2.07 \%$ median $=12.00 \%$ respectively), but it became significant for the irradiation dose of $14.4 \mathrm{~J} / \mathrm{cm}^{2}$ (mean $=18.60 \pm$ $2.07 \%$ - median $=19 \%$ ), suggesting that some blue light induced DNA-lesions turned into unrepaired doublestrand breaks, leading to stable and heritable chromosomal damages.

FIGURE 4. Examples of binucleated keratinocytes with micronuclei
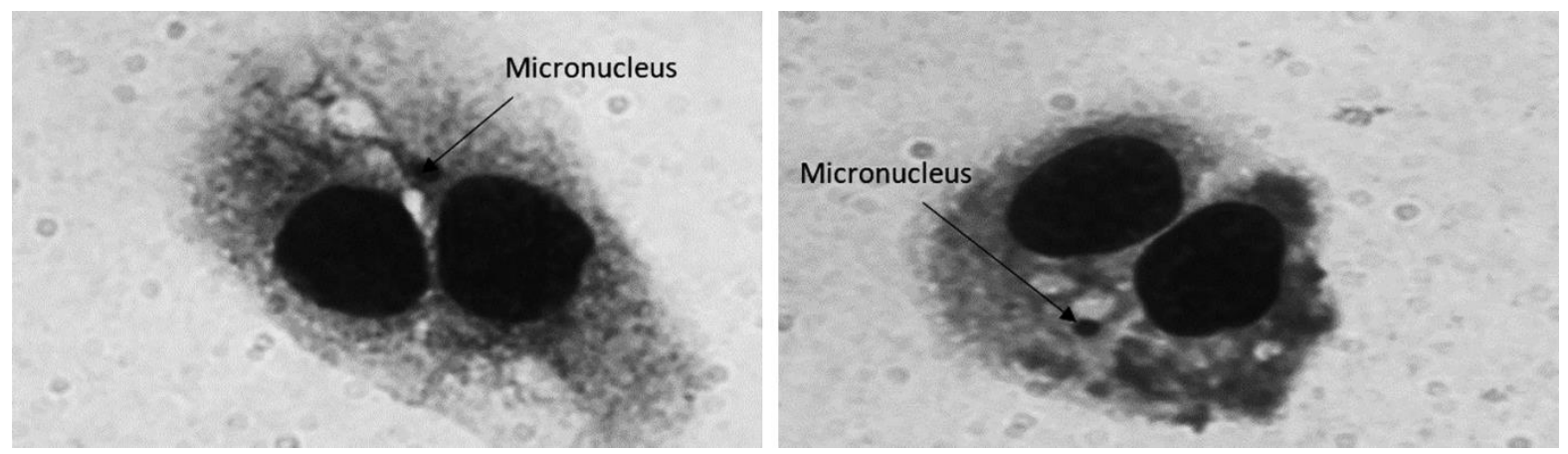

TABLE 1. Mutagenic impact of UVA/visible, UVB, and blue light in human keratinocytes by the micronucleus assay

\begin{tabular}{|c|c|c|c|c|c|c|c|c|c|}
\hline \multirow{2}{*}{\multicolumn{2}{|c|}{ Samples }} & \multicolumn{8}{|c|}{ Micronucleated cell rates \%。 } \\
\hline & & MNC-1 & MNC-2 & MNC-3 & MNC-4 & MNC-5 & $M e a n \pm S D$ & Median & $P$ \\
\hline \multicolumn{2}{|c|}{ Non-irradiated cells } & 11 & 8 & 10 & 10 & 5 & $8.80 \pm 2.39$ & 9.40 & \\
\hline \multicolumn{2}{|c|}{ UVA $0.08 \mathrm{~J} / \mathrm{cm}^{2}$} & 34 & 30 & 29 & 33 & 31 & $31.40 \pm 2.07$ & 31.00 & *** \\
\hline \multicolumn{2}{|l|}{ UVB $15 \mathrm{~J} / \mathrm{cm}^{2}$} & 20 & 19 & 14 & 15 & 16 & $16.80 \pm 2.59$ & 16.00 & $* * *$ \\
\hline \multirow{3}{*}{$\begin{array}{l}\text { Blue-light } \\
\text { irradiated cells }\end{array}$} & $4.8 \mathrm{~J} / \mathrm{cm}^{2}$ & 10 & 11 & 9 & 10 & 9 & $9.80 \pm 0.84$ & 9.90 & \\
\hline & $9.6 \mathrm{~J} / \mathrm{cm}^{2}$ & 12 & 13 & 12 & 16 & 11 & $12.60 \pm 2.07$ & 12.00 & \multirow[b]{2}{*}{$* * *$} \\
\hline & $14.4 \mathrm{~J} / \mathrm{cm}^{2}$ & 20 & 17 & 16 & 19 & 21 & $18.60 \pm 2.07$ & 19.00 & \\
\hline
\end{tabular}

MNC-1, ..., MNC-5: Micronucleated cell rates observed in 1,000 binucleated cells ( $\%$ )

$P$ : Probability of the difference between micronucleated cell rates of non-irradiated cells and the other cells analyzed by the Chi-squared test $(* * *: \mathrm{P}<0.001)$ 


\section{Discussion}

In the present study, the alkaline comet assay and the micronucleus assay were used to characterize the genotoxic impact of blue light in skin cells and to evaluate the cellular response to blue light induced DNAdamage. Irradiation by $415 \mathrm{~nm}$ wavelength, from the exposure dose of $9,6 \mathrm{~J} / \mathrm{cm}^{2}$, clearly induced dosedependent DNA-damage in human keratinocytes and confirmed previously published data observed in both skin and retinal epithelial cells. ${ }^{7,14}$

DNA-lesions were significantly enhanced in the presence of FPG, suggesting that blue light induced oxidative DNA-damage. This data was consistent with previously published studies which established that blue wavelengths could interact with intracellular porphyrins and flavoproteins to generate reactive oxygen species (ROS) ${ }^{9,25,26}$ such as superoxide, nitric oxide and peroxynitrite. ${ }^{27}$ In UVA-irradiated cells, the indirect formation of oxidized DNA bases through excited chromophores is considered the main genotoxic mechanism leading to the formation of 8-oxo-guanine and in a lower extend, DNA strand breaks and oxidized pyrimidines. ${ }^{28,}{ }^{29}$ We could suppose that blue-light may induce oxidative DNA-damage according to the same mechanisms as UVA, through an indirect oxidative process.

Surprisingly, DNA-lesions were significantly increased in the presence of T4 endo V, suggesting that blue light could also induce CPD-lesions. CPD-lesions are mainly due to high-energy photons, which are directly absorbed by DNA bases, and allow the formation of covalent bonds between two adjacent pyrimidines. ${ }^{30,31}$ They have been shown the predominant DNA-damage induced by UVB. Since UVA are not directly absorbed by the pyrimidine bases of DNA, the formation of CPD has long been considered negligible during UVA exposure. However, various recent studies have established that the majority of lesions induced on DNA by UVA are T-T type CPD. ${ }^{30,32}$ These lesions would derive from a Type I photosensitization mechanism, due to an energy transfer from a cell chromophore to the DNA rather than a direct excitation, as it is the case for UVB-induced CPD. ${ }^{33}$ The CPD lesions observed in the present study suggested that, similarly to UVA, blue wavelengths may oxidize cellular targets to induce T-T dimers.

Two DNA-repair kinetics were obtained in human keratinocytes irradiated with blue light. In FPG-treated nuclei, a rapid decrease of oxidative DNA-damage could be observed within the first 40 minutes post-irradiation. This DNA-repair kinetic was consistent with previously published data concerning UVA-induced oxidative DNAdamage: oxidized bases are rapidly eliminated by the Base Excision Repair (BER) and, after one hour, almost all the DNA-lesions are repaired. ${ }^{34}$ In T4 Endo V-treated nuclei, the decrease of blue light induced DNA-damage was slower, and $18 \%$ of the CPD-lesions remained unrepaired after 24 hours. This DNA-repair kinetic rate was consistent with previously published data observed in UVB-irradiated cells, suggesting the involvement of the Nucleotide Excision Repair (NER), intended to remove a wide range of DNA distorting lesions, such as CPD and 6-4 photoproducts, through a mechanism more complex than BER.

Results observed with the micronucleus assay demonstrated for the first time that a blue light could exert a clastogenic/aneugenic effect in human keratinocytes, leading to heritable chromosome aberrations.

Micronuclei are defined as chromosome fragments or whole chromosomes, which have been lost during cell mitosis, and form individual nuclear particles in the cytoplasm of daughter cells. ${ }^{23}$ In the present study, it was not possible to selectively differentiate whole chromosomes and chromosome fragments since no FISHtechnique was applied. However, the diameter of micronuclei has been proposed as an indicator of a clastogenic or aneugenic activity, acentric chromosome fragments being characterized by diameters lower than $25 \%$ of cell diameter. ${ }^{35}$ In cells exposed to genotoxic compounds or radiations, it has been shown that a strong proportion of micronuclei arises from clastogenic events, through unrepaired double-strand DNA-breaks. ${ }^{17}$ Our results confirmed this hypothesis, since almost all the micronuclei diameters observed in UVA, UVB and blue light irradiated cells were lower than $10 \%$ of the cell diameter. A great variety of mechanisms may transform the different DNA-lesions into acentric chromosome fragments, particularly when DNA-damage exceeds the DNArepair capacities. ${ }^{17}$ Oxidative DNA-lesions, such as 8-oxodeoxyguanosine, when they are in proximity or on opposite DNA-strands, may generate double-strand breaks through simultaneous excision-repair mechanisms of the BER repair pathway. Similarly, simultaneous excision events, related to the NER repair pathway, involved in the removal of DNA-lesions such as pyrimidine dimers, may also produce double strand-breaks. The presence of micronuclei in binucleated human keratinocytes may be considered a severe DNA damage since genes present in the extranuclear DNA-fragments are under-expressed or over-expressed, resulting in important phenotypic 
modifications. In survival cells, chromosome abnormalities are probably transmitted from parent cells to daughter cells, leading to chromosome rearrangement and instability. ${ }^{36}$

The cellular impact of blue light is being increasingly investigated. But conversely, with well documented damage described on the cornea, the consequences of blue light exposure to human skin cell DNA are less predictable and have not been deeply explored yet. Results observed in the present study suggested that a single $415 \mathrm{~nm}$ exposure generates both oxidized DNA-bases and CPD that may turn into heritable chromosome aberrations. Moreover, human exposure to visible light, and thus to blue light, during the daily activities of life is permanent (outside, inside, behind a window), while exposure to UVA is limited to outdoor activities during the daylight. Low-dose cumulative exposures to blue light could thus induce deleterious effects that contribute to premature skin-ageing. Further in vitro and in vivo studies are necessary to investigate the genotoxic potential of blue-light and to evaluate its impact in pre-cancer skin-lesions. As interindividual variations have been shown to play an important role in human carcinogenesis through variations in intracellular oxidative/antioxidative balance or in DNA-repair pathways, experiments should be anticipated in extended cell or skin samples. ${ }^{37}$ In addition, experiments should be proposed to evaluate the cumulative genotoxic effects of low dose repeated blue-light irradiations to better mimic the long-term human exposure.

\section{Conflict of interest}

None declared.

\section{References}

1. Rabstein S, Burek K, Lehnert M, Beine A, Vetter C, Harth V, Putzke S, Kantermann T, Walther J, WangSattler R, Pallapies D, Brüning T, Behrens T. Differences in twenty-four-hour profiles of blue-light exposure between day and night shifts in female medical staff. Sci Total Environ 2019; 653:1025-1033.

2. Wolf C, Wolf S, Weiss M, Nino G. Children's Environmental Health in the Digital Era: Understanding Early Screen Exposure as a Preventable Risk Factor for Obesity and Sleep Disorders. Children 2018;31:2-8.

3. Yoshino F, Yoshida A. Effects of blue-light irradiation during dental treatment. Jpn Dent Sci Rev 2018;54:160-168.

4. Taoufik K, Mavrogonatoub E, Eliades T, Papagiannoulisa L, Eliadesd G, Kletsasb D. Effect of blue light on the proliferation of human gingival fibroblast. Dent Mater 2008;24:895-900.

5. Xie C, Li X, Tong J, Gu Y, Shen Y. Effects of white light-emitting diode (LED) light exposure with different Correlated Color Temperatures (CCTs) on human lens epithelial cells in culture. Photochem Photobiol 2014;90:853-859.

6. Wall AC, Gius JP, Buglewicz DJ, Banks A, Kato TA. Oxidative stress and endoreduplication induced by blue light exposure to CHO cells. Mutat Res Gen Tox En 2019;841:31-35.

7. Sparrow JR, Zhou J, Cai B. DNA is a target of the photodynamic effects elicited in A2E-laden RPE by bluelight illumination. Invest Ophthalmol Vis Sci 2003;44:2245-51.

8. Gomes CC, Preto S. 6th International Conference on Applied Human Factors and Ergonomics (AHFE 2015) and the Affiliated Conferences, AHFE 2015. Blue light: A blessing or a curse? Procedia Manufacturing 2015;3:4472 - 4479.

9. Nakashima Y, Ohta S, Wolf AM. Blue light-induced oxidative stress in live skin. Free Radic Biol Med 2017;108:300-310.

10. Ash C, Dubec M, Donne K, Bashford T. Effect of wavelength and beamwidth on penetration in light-tissue interaction using computational methods. Lasers Med Sci 2017;32:1909-1918.

11. Opländer C, Hidding S, Werners FB, Born M, Pallua N, Suschek CV. Effects of blue light irradiation on human dermal fibroblasts. J Photochem Photobiol B Biol 2011;103:118-125.

12. Vandersee S, Beyer M, Lademann J, Darvin ME. Blue-Violet light irradiation dose dependently decreases carotenoids in human skin, which indicates the generation of free radicals. Oxid Med Cell Longev 2015;ID579675:7 pages. 
13. Avola R, Graziano ACE, Pannuzzo G, Cardile V. Blue Light induces down-regulation of aquaporin 1 , 3, and 9 in human keratinocytes. Cells 2018;7:197.

14. Dong K, Goyarts E, Pelle E, Trivero J, Pernodet N. Blue light disrupts the circadian rhythm and creates damage in skin cells. Int J Cosmet Sci 2019;41:558-562.

15. Wischermann K, Boukamp P, Schmezer P. Improved alkaline comet assay protocol for adherent HaCaT keratinocytes to study UVA-induced DNA damage. Mutat Res 2007;630:122-128.

16. Jean S, De Meo M, Sabatier AS, Laget M, Hubaud JC, Verrando P, Dumenil G. Evaluation of sunscreen protection in human melanocytes exposed to UVA or UVB irradiation using the alkaline comet assay. Photochem Photobiol 2001;74(3):417-423.

17. Fenech M, Kirsch-Volders M, Natarajan AT, Surralles J, Crott JW, Parry J, Norppa H, Eastmond DA, Tucker JD, Thomas P. Molecular mechanisms of micronucleus, nucleoplasmic bridge and nuclear bud formation in mammalian and human cells. Mutagenesis 2011;26:125-132.

18. Repetto G, Del Peso A, Zurita JL. Neutral red uptake assay for the estimation of cell viability/cytotoxicity. Nat Protoc 2008;3(7):1125-31.

19. Singh NP, McCoy MT, Tice RR, Schneider EL. A simple technique for quantitation of low levels of DNA damage in individual cells. Exp Cell Res 1988;175:184-191.

20. Azqueta A, Leire Arbillaga L, López de Certain A, Collins A. Enhancing the sensitivity of the comet assay as a genotoxicity test, by combining it with bacterial repair enzyme FPG. Mutagenesis 2013;28:271-277.

21. Lo HL, Nakajima S, Ma L, Walter B, Yasui A, Ethell DW, Owen LB. Differential biologic effects of CPD and 6-4PP UV-induced DNA damage on the induction of apoptosis and cell-cycle arrest. BMC Cancer 2005;5:135.

22. Bauer E, Recknagel RD, Fiedler U, Wollweber L, Bock C, Greulich KO. The distribution of the tail moment in single cell gel electrophoresis (comet assay) obeys a chi-square $(\chi 2)$ not a gaussian distribution. Mutat Res 1998;398:101-110.

23. Fenech M, Bonassi S, Turner J, Lando C, Ceppi M, Chang WP, Holland N, Kirsch-Volders M, Zeiger E, Bigatti MP, Bolognesi C, Cao J, De Luca G, Di Giorgio M, Ferguson LR, Fucic A, Lima OG, Hadjidekova VV, Hrelia P, Jaworska A, Joksic G, Krishnaja AP, Lee TK, Martelli A, McKay MJ, Migliore L, Mirkova E, Muller WU, Odagiri Y, Orsiere T, Scarfi MR, Silva MJ, Sofuni T, Surralles J, Trenta G, Vorobtsova I, Vral A, Zijno A. Intra and inter-laboratory variation in the scoring of micronuclei and nucleoplasmic bridges in binucleated human lymphocytes. Results of an international slide-scoring exercise by the HUMN project. Mutat Res 2003;534:45-64.

24. Snijders AM, Mannion BJ, Leung SJ, Moon SC, Kronenberg A, Wiese C. Micronucleus Formation in Human Keratinocytes is Dependent on Radiation Quality and Tissue Architecture. Environ Mol Mutagen 2015;56:22-31.

25. Godley BF, Shamsi FA, Liang F, Jarrett SG, Davies S, Boulton M. Blue Light Induces Mitochondrial DNA Damage and Free Radical Production in Epithelial Cells. J Biol Chem 2005;280:21061-21066.

26. Omata Y, Lewis JB, Rotenberg S, Lockwood PE, Messer RLW, Noda M, Hsu SD, Sano H, Wataha JC. Intraand extracellular reactive oxygen species generated by blue light. J Biomed Mater Res 2006;A77:470477.

27. Opländer C, Deck A, Volkmar CM, Kirsch M, Liebmann J, Born M, van Abeelen F, van Faassen EE, Kröncke KD, Windolf J, Suschek CV. Mechanism and biological relevance of blue-light (420-453 nm)-induced nonenzymatic nitric oxide generation from photolabile nitric oxide derivates in human skin in vitro and in vivo. Free Radic Biol Med 2013;65:1363-1377.

28. Pfeifer GP, Besaratinia A. UV wavelength-dependent DNA damage and human non-melanoma and melanoma skin cancer. Photochem Photobiol Sci 2012;11:90-97.

29. Tewari A, Sarkany RP, Young AR. UVA1 induces cyclobutane pyrimidine dimers but not 6-4 photoproducts in human skin in vivo. J Invest Dermatol 2012;132:394-400.

30. Douki T, Cadet J. Individual determination of the yield of the main UV-induced dimeric pyrimidine photoproducts in DNA suggests a high mutagenicity of CC photolesions. Biochemistry 2001;40:2495501. 
31. Mitchell DL. Effects of cytosine methylation on pyrimidine dimer formation in DNA. Photochem Photobiol 2000;71:162-165.

32. Mouret S, Baudouin C, Charveron M, Favier A, Cadet J, Douki T. Cyclobutane pyrimidine dimers are predominant DNA lesions in whole human skin exposed to UVA radiation. Proc Natl Acad Sci U S A 2006;103:13765-13770.

33. Douki T, Reynaud-Angelin A, Cadet J, Sage E. Bipyrimidine photoproducts rather than oxidative lesions are the main type of DNA damage involved in the genotoxic effect of solar UVA radiation. Biochemistry 2003;42:9221-9226.

34. Cadet J, Davies KJA. Oxidative DNA damage \& repair: An introduction. Free Radic Biol Med 2017;107:212.

35. Tinwell H, Ashby J. Micronucleus morphology as a means to distinguish aneugens and clastogens in the mouse bone marrow micronucleus assay. Mutagenesis 1991;6:193-198.

36. Hintzsche H, Hemmann U, Poth A, Utesch D, Lott J, Stopper H. Fate of micronuclei and micronucleated cells. Mutat Res 2017;771:85-98.

37. Panel S, Mouret M, Leccia J, Bourrain T, Douki T, Beani JC. Individual Photosensitivity of Human Skin and UVA-Induced Pyrimidine Dimers in DNA. J Invest Dermatol 2011;131(7):1539-1546 